\title{
Effect of PMSG on follicular atresia in the immature rat ovary
}

\author{
Ruth H. Braw and A. Tsafriri
}

Department of Hormone Research, The Weizmann Institute of Science, Rehovot, Israel

\begin{abstract}
Summary. Administration of PMSG to 26-day-old rats did not increase the total number (non-atretic and atretic) of preantral (Type 4) and antral (Types 5 and 6) follicles but changed the proportion between non-atretic and atretic follicles. By $12 \mathrm{~h}$ after PMSG administration only $7 \%$ of Type 5 follicles were atretic, and no atretic follicles of Type 6 were observed, as compared to 52 and $62 \%$ atretic follicles, respectively, in the saline-treated controls. PMSG did not decrease the percentage of atresia in preantral (Type 4) follicles. The treatment was associated with a sharp fall by $12 \mathrm{~h}$ in the pyknotic index of antral (Types 5 and 6 ) follicles. It is concluded that PMSG causes superovulation in the rat by rescuing follicles of Types 5 and 6 from atresia and allowing them to reach ovulation.
\end{abstract}

\section{Introduction}

The dependence of medium-sized and large follicles on gonadotrophins for normal growth and differentiation is known (Greenwald, 1974; Richards, Rao \& Ireland, 1978). However, the exact stage of follicular growth at which the dependence on pituitary hormones is established is yet to be determined. It has been suggested that the preovulatory surge of FSH is needed for the development of a cohort of follicles that will reach ovulation in the next cycle (Schwartz, 1969; Welschen, 1973; Hirshfield \& Midgley, 1978a).

The induction of superovulation by PMSG in rodents is a well established and widely used procedure. Whether this effect of PMSG is due to recruitment of follicles from the non-growing pool or to a decrease in the rate of atresia is apparently specific to the species. In immature mice, administration of PMSG decreased the number of large atretic follicles and therefore it has been suggested that the action of gonadotrophin is to prevent atresia (Peters, Byskov, HimelsteinBraw \& Faber, 1975; Peters, 1979). On the other hand, in the ovary of the cyclic hamster PMSG decreases follicular atresia as well as recruits 'reserve' follicles (Chiras \& Greenwald, 1978a). In hypophysectomized immature rats high levels of gonadotrophins increased atresia (Harman, Louvet \& Ross, 1975). In the intact rat the role of gonadotrophins in follicular growth and atresia remains to be determined.

The purpose of this study was to examine the effect of PMSG on follicular growth and atresia in the immature rat ovary and to determine at which stage of follicular development the gonadotrophin exerted its effect. 


\section{Materials and Methods}

The Wistar-derived rats from the departmental colony were 26 days old when used. Each of 32 females received a subcutaneous injection of 15 i.u. PMSG (Gestyl: Organon) in 0.9\% (w/v) $\mathrm{NaCl}$ or $0.9 \% \mathrm{NaCl}$ only. In our rat colony, this dose of PMSG induces the release of $49.6 \pm$ $11.6 \mathrm{ova} /$ treated rat. The rats were killed by cervical dislocation at $6,12,24$ and $48 \mathrm{~h}$ after the injection (4 experimental and 4 control rats at each time). The ovaries were removed, fixed in Bouin's solution and after dehydration were embedded in paraffin wax, serially sectioned at $7 \mu \mathrm{m}$ and stained with haematoxylin-eosin or Heidenhain's Azan.

At histological examination a classification modified after that of Pedersen \& Peters (1968) was used to describe stages of follicle development (Table 1). Follicles with $>80$ granulosa cells per largest cross-section were counted in every fifth section using the nucleolus of the oocyte as a marker. For each largest cross-section of a follicle the following characteristics were evaluated: (i) the mitotic index was the percentage of granulosa cells in mitosis per total number of granulosa cells; and (ii) the pyknotic index, defined as the percentage of pyknotic granulosa cell nuclei per total number of granulosa cells.

Table 1. Classification of follicles in the rat ovary (modified after Pedersen \& Peters, 1968)

\begin{tabular}{|c|c|c|c|c|}
\hline $\begin{array}{l}\text { Follicle } \\
\text { type }\end{array}$ & $\begin{array}{l}\text { Oocyte } \\
\text { diam. } \\
(\mu \mathrm{m})\end{array}$ & $\begin{array}{c}\text { No. of } \\
\text { granulosa } \\
\text { cells/largest } \\
\text { cross-section }\end{array}$ & $\begin{array}{l}\text { Follicular } \\
\text { diam. }(\mu \mathrm{m})\end{array}$ & Antrum \\
\hline \multicolumn{5}{|l|}{ Small } \\
\hline 2 & $15 \cdot 5$ & $<15$ & $<50$ & - \\
\hline \multicolumn{5}{|l|}{ Medium } \\
\hline 3 & 37.6 & $15-80$ & $50-120$ & - \\
\hline 4 & 49.9 & $81-200$ & $120-170$ & $\begin{array}{l}\text { Scattered areas } \\
\text { of follicular } \\
\text { fluid }\end{array}$ \\
\hline \multicolumn{5}{|r|}{ IIn⿺⿻一𠃋十 } \\
\hline 5 & $56 \cdot 3$ & $201-600$ & $170-370$ & Present \\
\hline 6 & 58.0 & $600-1000$ & $370-500$ & Present \\
\hline \multicolumn{5}{|l|}{ Preovulatory } \\
\hline 7 & 57.4 & $>1000$ & $>500$ & Present \\
\hline
\end{tabular}

A distinction was made between non-atretic and atretic follicles and the stages of atresia in antral follicles were defined. All follicles with more than $1 \%$ pyknotic granulosa cell nuclei were classified as atretic. Statistical significance was determined by Student's $t$ test.

\section{Results}

\section{Stages of follicular atresia}

Non-atretic follicles (Pl. 1, Fig. 1) contained oocytes in the resting stage of prophase (dictyate), the mitotic index was $3.0 \pm 0 \cdot 1$ (s.e.m.), and pyknotic nuclei were absent. Follicular fluid was 'clean', i.e. without cell debris or macrophages. The theca interna consisted of a few layers of elongated cells.

Stage I atresia (Pl. 1, Fig. 2). The oocytes of these follicles were in the dictyate stage and 1$10 \%$ of the nuclei in the granulosa layer were pyknotic. Mitotic figures were seen but the mitotic index $(1.8 \pm 0.2)$ was significantly lower $(P<0.001)$ than in the non-atretic follicles. The follicular fluid contained some cell debris. 


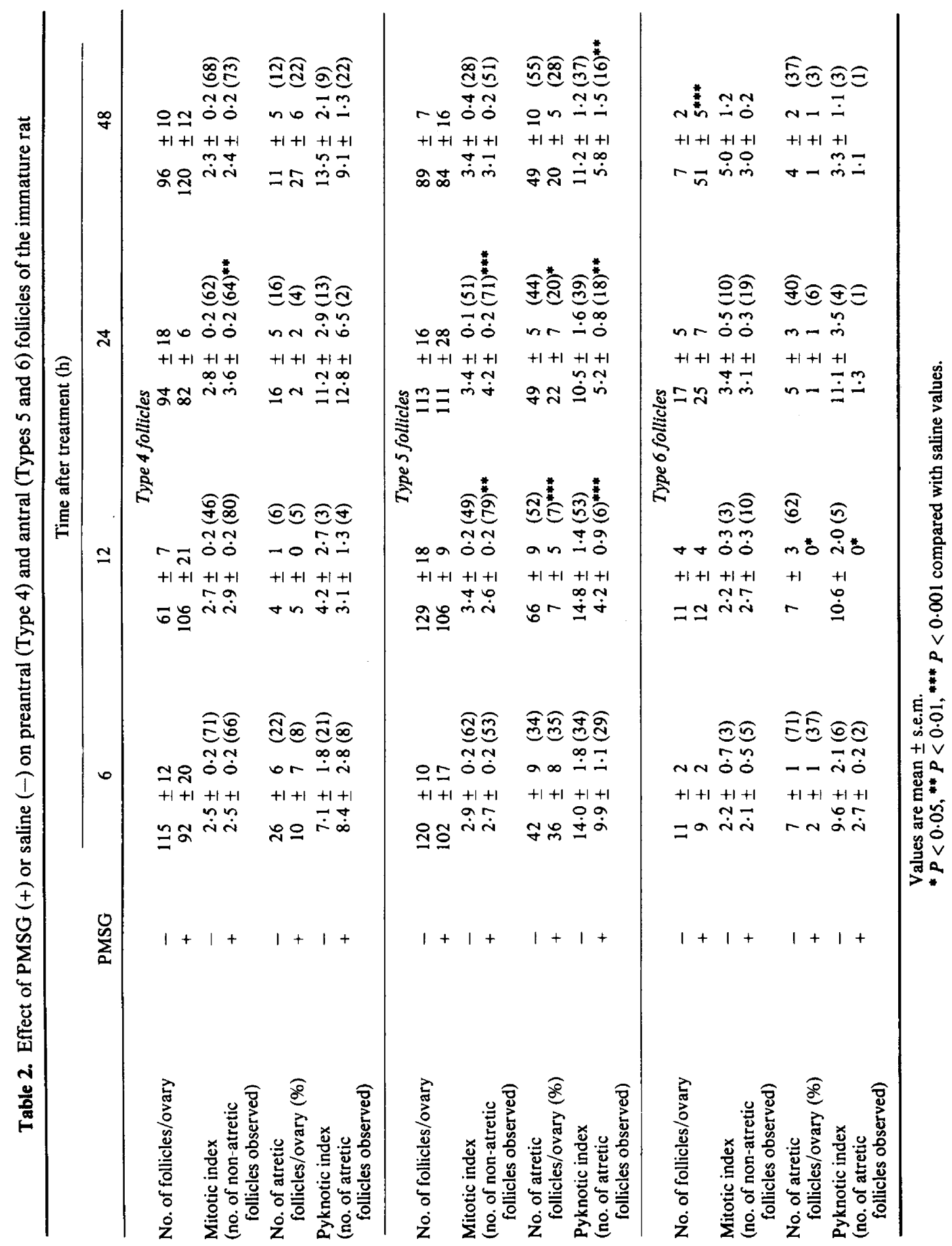


Stage II atresia (Pl. 1, Fig. 3). In most of the follicles meiosis-like changes such as chromosomes at metaphase or a polar body could be observed. In the granulosa layer 10-30\% of the nuclei were pyknotic, but mitotic figures could also still be seen. The mitotic index was 0.4 $\pm 0 \cdot 1$. Follicular fluid contained much cell debris.

Stage III atresia (Pl. 1, Fig. 4). The oocyte was fragmented or pseudocleaved. Most of the granulosa cells had disappeared and macrophages were seen in the follicular fluid. The theca interna was hypertrophied. As atresia progressed the follicle collapsed.

Although three stages of atresia were defined, only Stages I and II were used in the calculations because the follicle type could be determined accurately only at these stages by the number of granulosa cells and follicular diameter. In more advanced stages of atresia the reduced number of granulosa cells and the shrinking of the follicle obscured the follicle type in which the atresia began.

\section{Effect of PMSG on follicular populations}

Preantral follicles. Neither the total number of Type 4 follicles (non-atretic and atretic) nor the percentage of atretic follicles was changed by PMSG treatment (Table 2). The pyknotic index was similar at all times and the mitotic index showed a significant difference between follicles from saline and PMSG-treated rats only at $24 \mathrm{~h}$.

Antral follicles. The total number of Type 5 and Type 6 follicles did not differ until $48 \mathrm{~h}$ after PMSG treatment when there were more Type 6 follicles in the ovaries of PMSG-treated females (Table 2). The percentage of atretic follicles of both types was significantly decreased even by $12 \mathrm{~h}$ after PMSG administration, and the pyknotic index was also markedly lower after PMSG injection.

\section{Discussion}

The pattern of follicular atresia in the rat ovary that we have observed closely resembles the changes in the mouse ovary previously reported (Byskov, 1974). Administration of PMSG did not increase the total number of follicles (non-atretic and atretic) of Types 4, 5 and 6, suggesting that PMSG does not permit superovulation in the rat by recruiting follicles smaller than Type 4 into the pool of larger growing follicles. In the hamster ovary, however, an effect of PMSG on the growth of small preantral follicles has been observed (Chiras \& Greenwald, 1978a, b). In the sheep, rescue of follicles from atresia does not play a role in the increase in the number of follicles observed following administration in vivo of PMSG (Dott, Hay, Cran \& Moor, 1979). In the present study an effect of PMSG was only observed for follicles of Types 5 and 6, i.e. those $>200$ granulosa cells/largest cross-section. There was a change in the proportion of non-

\section{PLATE 1}

Rat ovaries were fixed in Bouin, dehydrated, embedded in paraffin wax and serially sectioned at $7 \mu \mathrm{m}$. Bar: $50 \mu \mathrm{m}$.

Fig. 1. Non-atretic antral follicle. The oocyte nucleus is in the dictyate stage, and there are no pyknotic granulosa cells. $\mathrm{H} \& \mathrm{E}$.

Fig. 2. Stage I of atresia. The oocyte is in the dictyate stage. Pyknotic nuclei are present in the granulosa layer (arrowheads). $\mathrm{H} \& \mathrm{E}$.

Fig. 3. Stage II of atresia. In the oocyte meiosis-like changes occur. The follicle fluid contains much cell debris. pb, polar body. $\mathrm{H} \& \mathrm{E}$.

Iig. 4. Stage III of atresia. The oocyte $\left(^{*}\right)$ is fragmented, the theca interna (ti) is hypertrophied and only a few granulosa cells (arrowheads) are left. The follicle is collapsed. Azan. 
PLATE 1

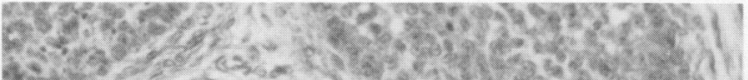

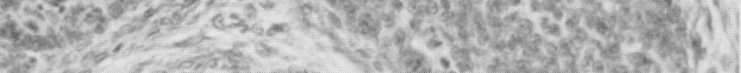

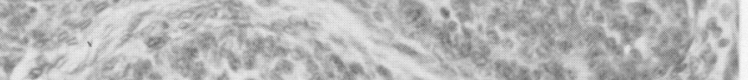

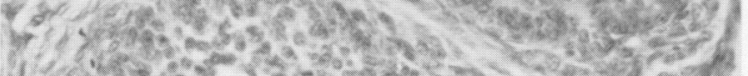
1. 1 4.

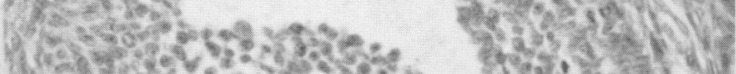

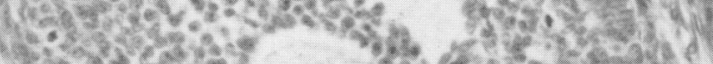
78.3 eares

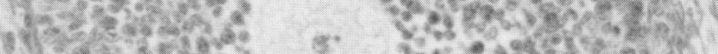
1.

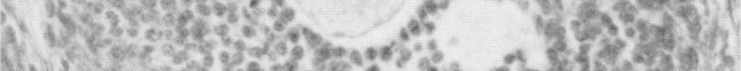

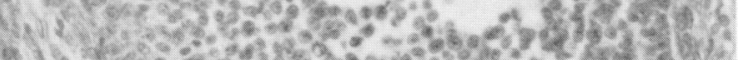

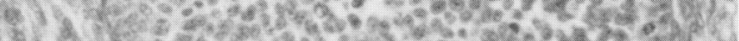

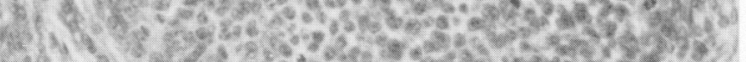

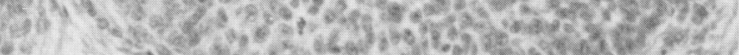

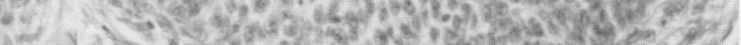

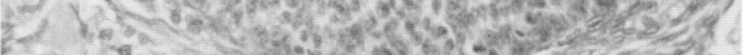

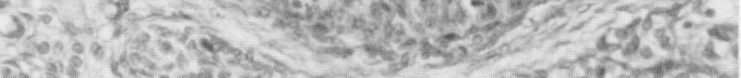
161 (1)

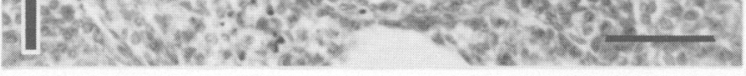
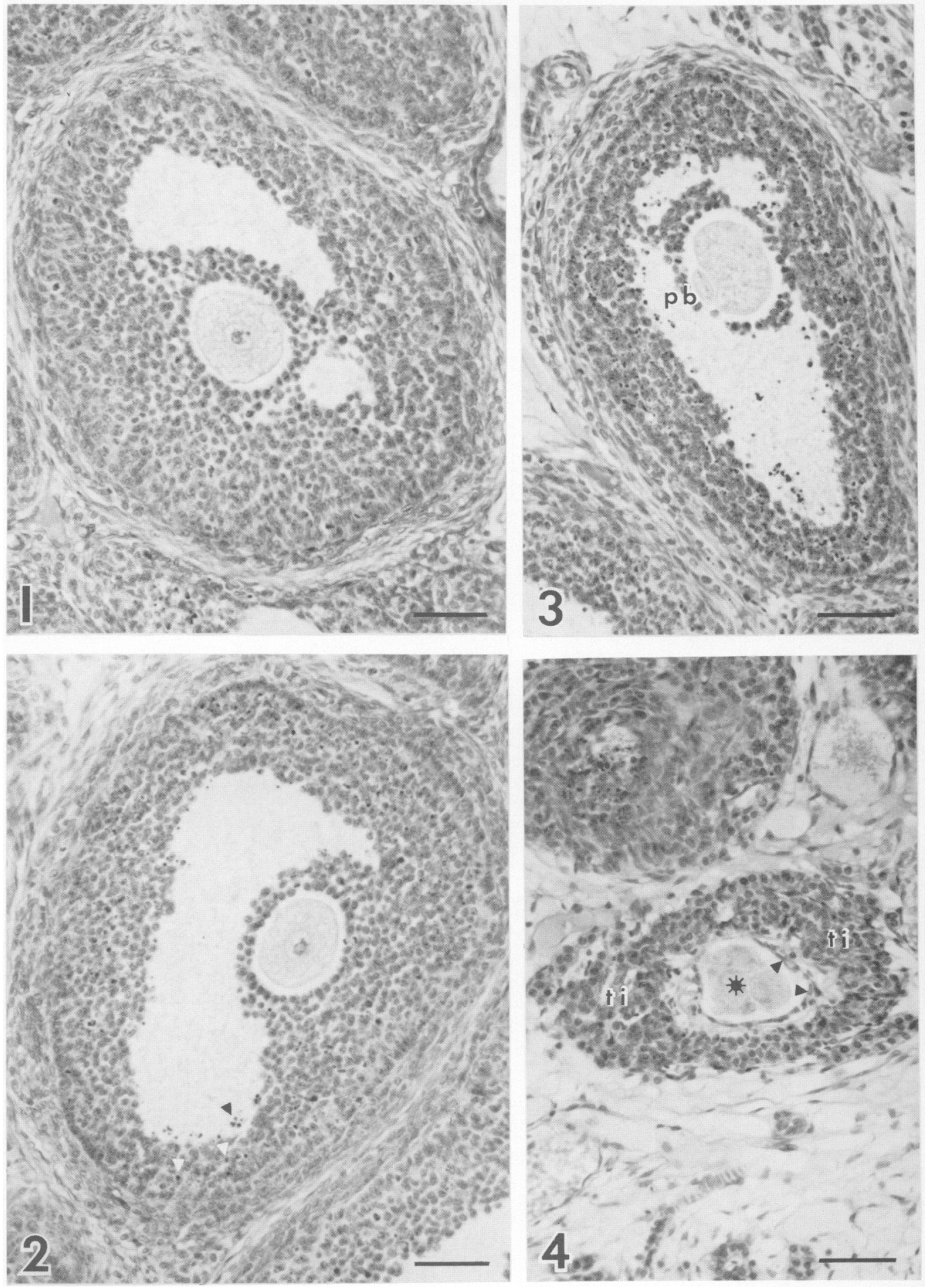
atretic and atretic follicles, indicating that PMSG significantly decreased atresia of antral follicles. A similar anti-atretic effect of PMSG on the large mouse follicles has been reported (Peters et al., 1975; Peters, 1976, 1979). Likewise, ovine atretic follicles become morphologically and probably steroidogenically indistinguishable from non-atretic follicles following PMSG (Hay \& Moor, 1978). The most characteristic feature of the effect of PMSG on rat atretic folicles was a sharp fall in the pyknotic index, observed even by $12 \mathrm{~h}$. A similar decrease in pyknotic index after PMSG administration was also demonstrated in the mouse ovary (Peters, 1979). Loss of degenerating cells and phagocytic bodies has been observed during regeneration (Hay, Moor, Cran \& Dott, 1979). Byskov (1979) suggested that PMSG induces the granulosa cells of atretic follicles to phagocytose the dying cells and thus rescues the follicle at an early stage of atresia. The short time interval between PMSG administration and the reduction in the pyknotic index observed in our study strongly supports this concept.

The increase in the total number of Type 6 follicles at $48 \mathrm{~h}$ after PMSG was probably due to the decrease in atresia of Type 5 follicles. The increase in mitotic index of Type 5 follicles $24 \mathrm{~h}$ after PMSG administration suggests that PMSG might increase granulosa cell proliferation in these follicles. A similar effect of FSH or PMSG on follicular cell proliferation has been reported for mice and rats (Pedersen, 1970; Rao, Midgley \& Richards, 1978; Peters, 1979).

By morphometric analysis of follicular development in cyclic rats Hirshfield \& Midgley (1978b) concluded that follicles of diameter $200-400 \mu \mathrm{m}$ (corresponding approximately to Type 5 follicles in our classification) are in a critical stage of development and, unless rescued, will become atretic. Administration of exogenous FSH 1 day before the endogenous surge of gonadotrophins caused the appearance of a cohort of follicles of 390-500 $\mu \mathrm{m}$ diameter (corresponding to our Type 6) 1 day earlier, i.e. on the day of pro-oestrus. Elimination of the gonadotrophin surge on the day of pro-oestrus by pentobarbitone sodium treatment prevented the appearance of follicles in the 390-500 $\mu \mathrm{m}$ range which are normally seen on the day of oestrus. This effect was overcome by the administration of FSH. It was inferred that the surge of FSH rescues the follicles in the $200-400 \mu \mathrm{m}$ range from atresia, thus allowing them to reach ovulation in the next cycle (Hirshfield \& Midgley, 1978a). Our study demonstrates a similar effect of PMSG in rescuing immature rat follicles of Types 5 and 6 from atresia. Oestrogen treatment prevents follicular atresia in hypophysectomized immature female rats (Harman et al., 1975) and it is possible that FSH and PMSG exert their anti-atretic action through the stimulation of follicular oestrogen production and this possibility needs to be studied.

We thank Professor H. R. Lindner for his interest; Professor S. H. Pomerantz and Dr A. Nimrod for advice; and $\mathrm{Mr}$ S. Yosef for devoted animal care. The contribution of R.H.B. constitutes part of the requirements for the Ph.D. degree of the Feinberg Graduate School of the Weizmann Institute of Science. The work was generously supported by the Population Council, New York, and the Ford Foundation.

\section{References}

Byskov, A.G.S. (1974) Cell kinetic studies of follicular atresia in the mouse ovary. J. Reprod. Fert. 37, 277285.

Byskov, A.G. (1979) Atresia. In Ovarian and Follicular Development and Function, pp. 41-57. Eds A. R. Midgley \& W. A. Sadler. Raven Press, New York.

Chiras, D.D. \& Greenwald, G.S. (1978a) Ovarian follicular development in cyclic hamster treated with a superovulatory dose of Pregnant Mare's Serum. Biol. Reprod. 19, 895-901.
Chiras, D.D. \& Greenwald, G.S. (1978b) Effects of steroids and gonadotropins on follicular development in the hypophysectomized hamster. Am. J. Anat. 152, 307-320.

Dott, H.M., Hay, M.F., Cran, D.G. \& Moor, R.M. (1979) Effect of exogenous gonadotrophin (PMSG) on the antral follicle population in the sheep. $J$. Reprod. Fert. 56, 683-689.

Greenwald, G.S. (1974) Role of FSH and LH in follicular development and ovulation. In Handbook 
of Physiology Section 7: Endocrinology, pp. 293323. Eds R. O. Greep \& E. B. Astwood. Am. Physiol. Society, Washington, D.C.

Harman, S.M., Louvet, J.P. \& Ross, G.T. (1975) Interaction of estrogen and gonadotrophins on follicular atresia. Endocrinology 96, 1145-1152.

Hay, M.F. \& Moor, R.M. (1978) Changes in the Graafian follicle population during the follicular phase of the oestrous cycle. In Control of Ovulation, pp. 177-196. Eds D. B. Crighton, G. R. Foxcroft, N. B. Haynes \& G. E. Lamming. Butterworths, London.

Hay, M.F., Moor, R.M., Cran, D.G. \& Dott, H.M. (1979) Regeneration of atretic sheep ovarian follicles in vitro. J. Reprod. Fert. 55, 195-207.

Hirshfield, A.N. \& Midgley, A.R., Jr (1978a) The role of FSH in the selecting of large ovarian follicles in the rat. Biol. Reprod. 19, 606-611.

Hirshfield, A.N. \& Midgley, A.R., Jr (1978b) Morphometric analysis of follicular development in the rat. Biol. Reprod. 19, 597-605.

Pedersen, T. (1970) Cell population kinetics of the ovary of the immature mouse after FSH stimulation. In Gonadotrophins and Ovarian Development, pp. 312-324. Eds A. Butt, T. Crooke \& M. Ryle. E. \& S. Livingstone, Edinburgh.

Pedersen, T. \& Peters, H. (1968) Proposal for a classification of oocytes and follicles in the mouse ovary. J. Reprod. Fert. 17, 555-557.
Peters, H. (1976) The development and maturation of the ovary. Annls Biol. anim. Biochim. Biophys. 16, 271278.

Peters, H. (1979) Some aspects of early follicular development. In Ovarian Follicular Development and Function, pp. 1-13. Eds A. R. Midgley \& W. A. Sadler. Raven Press, New York.

Peters, H., Byskov, A.G., Himelstein-Braw, R. \& Faber, M. (1975) Follicular growth: the basic event in the mouse and human ovary. $J$. Reprod. Fert. 45, 559566.

Rao, M.C., Midgley, A.R., Jr \& Richards, J.S. (1978) Hormonal regulation of ovarian cellular proliferation. Cell 14, 71-78.

Richards, J.S., Rao, M.C. \& Ireland, J.J. (1978) Actions of pituitary gonadotrophins on the ovary. In Control of Ovulation, Chapter 12, pp. 197-216. Eds D. B. Crighton, G. R. Foxcroft, N. B. Hayness \& G. E. Lamming. Butterworth, London.

Schwartz, N.B. (1969) A model for regulation of ovulation in the rat. Recent Prog. Horm. Res. 25, 154.

Welschen, R. (1973) Amounts of gonadotrophins required for normal follicle growth in hypophysectomized adult rats. Acta endocr., Copenh. 72, 137155 .

Received 13 July 1979 